\title{
Traditional Fermented Butter Smen/Dhan: Current Knowledge, Production and Consumption in Algeria
}

\author{
Rania Boussekine ${ }^{1}$, Ryma Merabti ${ }^{1,2}$, Malika Barkat ${ }^{1}$, Fatima-Zohra Becila ${ }^{1}$, Nora Belhoula ${ }^{1}$, Jérôme Mounier $^{3}$ \\ $\&$ Farida Bekhouche ${ }^{1}$ \\ ${ }^{1}$ Université Frères Mentouri Constantine 1, Laboratoire de la Biotechnologies et des Qualités des aliments \\ (BIOQUAL), Institut de la Nutrition, de l'Alimentation et des Technologies Agro-Alimentaires (INATAA), Route \\ de Ain-El-Bey, 25000 Constantine, Algeria \\ ${ }^{2}$ Université d'Abbes Laghrour, Département de biologie cellulaire et moléculaire, 40000 Khenchela, Algeria \\ ${ }^{3}$ Univ Brest, Laboratoire Universitaire de Biodiversité et Ecologie Microbienne, F-29280 Plouzané, France \\ Correspondence: Rania Boussekine, Université Frères Mentouri Constantine 1, Laboratoire de la \\ Biotechnologies et des Qualités des aliments (BIOQUAL), Institut de la Nutrition, de l'Alimentation et des \\ Technologies Agro-Alimentaires (INATAA), Route de Ain-El-Bey, 25000 Constantine, Algeria. E-mail: \\ rania.boussekine@umc.edu.dz
}

Received: May 4, $2020 \quad$ Accepted: June 5, $2020 \quad$ Online Published: July 16, 2020

doi:10.5539/jfr.v9n4p71 URL: https://doi.org/10.5539/jfr.v9n4p71

\begin{abstract}
Algerian Smen/Dhan is an ethnic dairy product which is a traditional fermented butter made from whole raw milk by empirical methods. This product constitutes a significant part of the Algerian diet and represents a gastronomical heritage that need to be preserved and protected. The aim of the present study was to investigate the place and use of this product in the Algerian culture as well as to identify the traditional methods used for its preparation. A survey was conducted on 880 households in the South and East of Algeria. The results revealed that $96.47 \%$ of the surveyed population knew what Smen/Dhan was, $75.22 \%$ consumed it and $47.61 \%$ prepared it at home. Concerning the production method, raw milk (cow, goat and/or sheep milk) is spontaneously fermented until coagulation. Then, the obtained coagulum (Raib) is churned with different tools to obtain the butter used for Smen/Dhan preparation. Then, two different preparation modes are used depending on the surveyed regions. Households from Batna, Khenchela and Setif proceed directly with butter salting while in the Biskra, Jijel, El Oued and Ouargla regions, a different process is used which first involves a heat-treatment of the butter followed by the addition of one or more ingredients. After packing in a traditional ceramic container (Ezzir) and other containers, a maturation step is applied with a long duration varying from one month to several years. This product is consumed as an additive to enhance the taste and aroma of some traditional dishes (couscous/other) and is also used in traditional medicine.
\end{abstract}

Keywords: Smen/Dhan, Algeria, survey, traditional preparation, consumption

\section{Introduction}

Nowadays, there is an increasing interest for foods that are linked with specific places or territories. Indeed, consumers are more and more attracted to local foods with a traditional character or image, and such local foods are often perceived as to be of higher quality, freshness, more sustainable and contributing to support the local economy (Pieniak, Verbeke, Vanhonacker, Guerrero, \& Hersleth, 2009). Among traditional foods, fermented foods have been consumed since antiquity and still constitute a main food source in the population's diet throughout the world. They also represent an important part of human dietary and culinary culture and most of these products are produced at household level or in small enterprise using spontaneous fermentation (El Sheikha, \& Hu, 2018; Johansen, Owusu-Kwarteng, Parkouda, Paonou, \& Jesperen, 2020).

Among fermented foods, dairy products are very popular due to their simple formulation. Milk as a raw material is well suited to support the growth of microorganisms because it is rich in carbon and nitrogen sources as well as micronutrients. Indeed, the ability to maintain it in a fresh state is limited, especially in warm environments and in the absence of a cold chain (Hutkins, 2006; Puniya, 2015), as these latter conditions will rapidly lead to its spoilage; that is the reason why different methods have been developed to allow its preservation for longer 
periods. Among these methods, milk fermentation is one of the most ancient practices to ensure milk preservation as it guarantees the availability of safe and nutritious foods throughout the year, and prevents the risk of shortage of dairy products to consumers (Abd-El Salam, \& Benkerroum, 2006).

Many types of fermented milk products exist throughout the world. Their organoleptic properties depend on different factors such as the animal species from which milk it is obtained, milk pre-treatment, conditions of fermentation and associated microbiota, and subsequent processing (Zamfir et al., 2006).

In Algeria, a large variety of dairy products are prepared with naturally fermented milk. They have played and still play a major role in people's diet, especially those from rural areas. Among them, Lben, Raib, Zebda, Dhan or Smen and Jben are the most common and are mostly marketed throughout informal circuits (Idoui, Benhamada, \& Leghouchi, 2010).

Smen or Dhan is a traditional fermented butter which is made from raw milk, cream or butter originating from several animal species (Rajorhia, 1993; Guessas, Adjoudj, Hadadji, \& Kihal, 2012; Iradukunda, Aida, Ouafi, Barkouch, \& Boussaid, 2018). Its fermentation can last from a few months to several years, depending on the moisture, humidity and room temperature of the storage place (Kacem, \& Karam, 2006). It is produced in many countries around the world, in Asia, the Middle-East and Africa (Afsaneh, Hosseinpour, \& Mina, 2016) and its name and preparation methods differ from one region to another. In Algeria, it is known as Dhan or Smen (Bensalah, Labtar, Delorme, \& Renault, 2011; Guessas, Adjoudj, Hadadji, \& Kihal, 2012), Smen in Morocco (Tantaoui-Elaraki, \& El Marrakchi, 1987; Benkerroum, \& Tamime, 2004; Faid et al., 1993; Sakili, \& Isoual, 2003 Iradukunda, Ouafi, Barkouch, \& Boussaid, 2018), Ghee in India and Ethiopia (Dhurvey, Kawtikwar, \& Sakarkar, 2012; Mortensen, 2016; Alganesh, \& Yetenayet, 2017), Samna in Egypt and Samin in Sudan (Sserunjogi, Abrahamsen, \& Narvhus, 1998).

This fermented butter is mostly used as a flavouring ingredient to improve the taste and aroma of many traditional dishes (Iradukunda, Aida, Ouafi, Barkouch, \& Boussaid, 2018). It is also used in traditional medicine for reducing pain associated with the cold feeling that accompanies coughs, rheumatism and bone trauma (Sakili, \& Isoual, 2003).

In Algeria, Smen/Dhan represents an ethnic heritage. It is manufactured according to an artisanal process, which is far from being perfectly known. A better knowledge of this product presents a scientific interest. In this context, the aim of the present study was thus to investigate the use and consumption of this traditional product as well as to identify how it is manufactured and stored in the Northeastern and Southeastern parts of Algeria.

\section{Material and Methods}

\subsection{Survey Study}

A field survey was conducted between May 2017 and March 2018 in different regions of the Southeast (Biskra, El Oued and Ouargla) and the Northeast of Algeria (Batna, Khenchela, Jijel and Setif) as shown in Figure 1. These regions were chosen based on a preliminary survey showing that Smen/Dhan preparation and consumption is quite common in these areas.

Families were asked about their practices and utilization of Smen/Dhan and the overall sample surveyed consisted of 880 households distributed in 71 towns from and nearby different localities, i.e., Batna, Biskra, El Oued, Jijel, Khenchela, Ouargla and Setif. The survey was mostly directed towards elder people especially women, dairy farmers, and farmers who are used to prepare Smen/Dhan and possibly market it in informal circuits in order to have a view as precise as possible on the practices associated with this traditional product. 


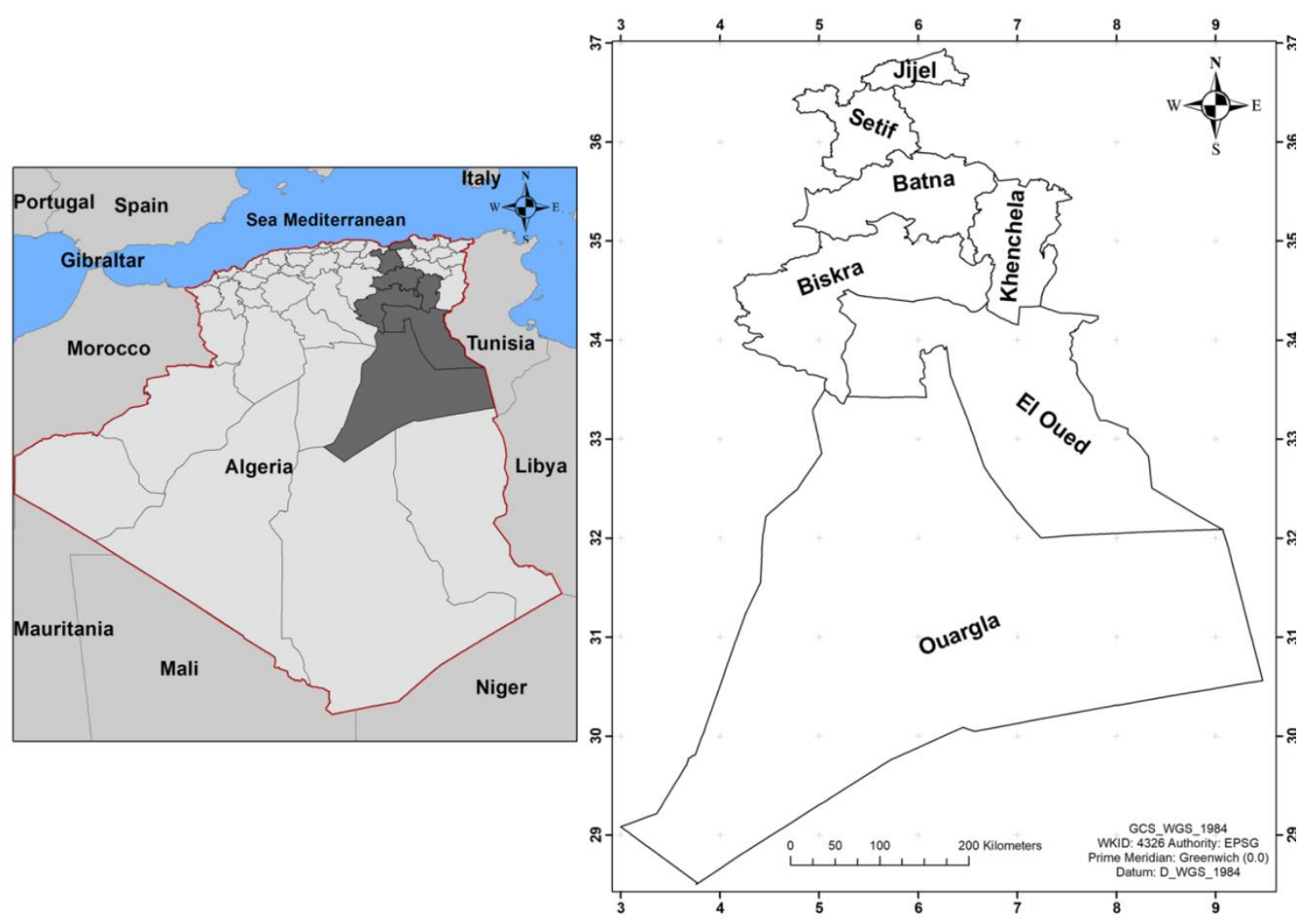

Figure 1. Detailed maps highlighting the surveyed regions of Algeria

\subsection{Data Collection}

Data were collected using a questionnaire and completed by face-to-face interviews. Before the beginning of the survey, the questionnaire framework and purpose was explained followed by the interview, which lasted about 15 to 20 minutes. Questions were read and if necessary, explained before collection of the answers.

\subsection{General Content of the Questionnaire}

The survey questionnaire contained forty-eight questions (supplementary file 1). It was divided into five parts. The first part of the questionnaire contained questions about the identity of the interviewed person (gender, age, education degree, professional activity and residence). The second part dealt with the profile of the business/enterprise where the product was produced. The third part allowed to gather information on the fermented product itself, i.e. the place of the fermented product in the local culture, its local name, the geographical production area, the mode and period of consumption as well as the product use. The fourth part included questions about the product organoleptic properties (texture, color, smell, taste...) and the fifth part concerned the description of the production process, the raw materials used and their origins, as well as the equipment used.

\subsection{Statistical Analysis}

Statistical analysis was performed using XL STAT, version 2014. The results of this study are presented using descriptive statistics and expressed as percentage of response to each question in the survey. ANOVA test was used to analyze the variance between modalities of each surveyed variables $(p<0.05)$. Correlation analysis was used to explore the relationship between the different parameters.

\section{Results and Discussion}

\subsection{Characteristics of the Studied Population and Link with Smen/Dhan Preparation}

Our study group consisted of 880 households and the interviewed persons were aged between 19 and 99 years old. As shown in Table 1, the surveyed population was overwhelmingly composed of adults over 38 years of age. The average and median age of the surveyed population was 49.47 and 50 years old, respectively. Over 55\% of 
respondents lived in urban areas.

After subdiving the surveyed persons into 20 year age-groups, we did not observe any relationship between age groups and preparation of Smen/Dhan in households, which indicates that Smen/Dhan preparation was performed indistinctively by all age groups. This result may be explained by the fact that Smen/Dhan preparation relies on a simple method of preparation in contrast to other traditional foods, such as couscous, which need much more effort and experience in their preparation. As an example, (Bekhouche, Merabti, \& Bailly, 2013) reported that couscous lemzeiet was mainly prepared by women that are aged between 40 and 60 years. On the other hand, we did not find any relationship between professional activity and Smen/Dhan preparation, this can be explained by the fact that the product preparation does not require a great effort, and its preparation is quick and easy.

The percentage of the surveyed females was higher than that of males, as $84.54 \%$ of the interviewed persons were females while only $15.45 \%$ were males. This observation is not surprising given the women's role in the manufacture of traditional products, including Smen/Dhan, and the fact that Smen/Dhan preparation is an activity exclusively realized by women. For all these women, the expertise or the art of Smen/Dhan making was passed on by their mothers, grandmothers or mothers-in-law as previously reported by Gagaoua and Boudchicha (2018) for ethnic meat products of the North African and Mediterranean countries. While keeping and preserving the same eating habits, the Smen/Dhan making process was considered by the interviewed persons as a precious legacy transmitted from one generation to another. In contrast, men play a relatively insignificant role in the Smen/Dhan preparation but are involved in selling tasks.

Table 1. Socio-demographic structure of the 880 surveyed persons

\begin{tabular}{lll}
\hline Surveyed population & Number & Percentage (\%) \\
\hline Age (years) & & \\
$19-38$ & 202 & 22.95 \\
$38-58$ & 424 & 48.18 \\
$59-78$ & 226 & 25.68 \\
$79-99$ & 28 & 3.18 \\
Gender & & \\
Female & 744 & 84.54 \\
Male & 136 & 15.45 \\
Region & & \\
Urban & 489 & 55.56 \\
Rural & 391 & 44.43 \\
Professional Activity & & \\
Housewives & 701 & 79.65 \\
Students & 29 & 3.29 \\
Civil servant & 133 & 14.77 \\
Retired & 17 & 1.93 \\
\hline
\end{tabular}

\subsection{Place of the Product in Local Culture}

Smen/Dhan is a traditional product very appreciated by the Algerian population. This product is part of the eating habits in different regions of Algeria. The results revealed that $96.47 \%$ of the surveyed population knew what Smen/Dhan was because of its importance in the Algerian kitchen (Table 2). Even if the product was not prepared by all Algerian families (47.6\% of households), its recognition by most families confirmed that this product is a traditional product of Algeria, which knowledge and utilization are transmitted from one generation to another. It is worth noting that the name used for this product, i.e. Smen or Dhan varied according to the surveyed region. Indeed, we found out that the majority of respondents used the name Dhan in all the surveyed regions (Batna, Biskra, El Oued, Khenchela, Setif, Ouargla), except for Jijel in which the name Smen was used.

Smen/Dhan is widely used by Algerian families. Indeed, $75.22 \%$ of the surveyed population consumed it on a regular basis. The interviewed persons also indicated that they consumed Smen/Dhan for its taste, i.e., as flavouring agent in traditional dishes, but also for the health benefits associated with its consumption.

Concerning people that did not prepare themselves Smen/Dhan, the purchase of Smen/Dhan was done in formal circuits if available on the market or informally through other households producing their own product. We noted that the price of one Kg of Dhan was 2000 DA in southern areas of Algeria (Biskra, El Oued, Ouargla) while it 
was 800 DA in Eastern areas. This price difference can be explained by the nature of the raw material used for its preparation in these two areas. Indeed, Smen/Dhan is prepared with goat's milk in the South and cow's milk in the East and goat's milk is more expensive than cow's milk.

Table 2. Distribution of the surveyed population according to knowledge, manufacture, consumption and purchase of Smen/Dhan in different regions of Algeria

\begin{tabular}{llllll}
\hline Regions (Wilayas) & $\begin{array}{l}\text { Number of } \\
\text { respondents }\end{array}$ & Knowledge (n) & Preparation (n) & $\begin{array}{l}\text { Purchase } \\
(\mathbf{n})\end{array}$ & $\begin{array}{l}\text { Consumption } \\
\text { (n) }\end{array}$ \\
\hline Batna & 100 & 100 & 46 & 38 & 77 \\
Biskra & 100 & 100 & 21 & 50 & 67 \\
El Oued & 100 & 100 & 53 & 42 & 73 \\
Jijel & 100 & 69 & 42 & 21 & 68 \\
Khenchela & 276 & 276 & 158 & 114 & 221 \\
Sétif & 104 & 104 & 48 & 33 & 79 \\
Ouargla & 100 & 100 & 51 & 31 & 77 \\
Total & 880 & 849 & 419 & 329 & 662 \\
\% & 100 & 96.47 & 47.61 & 37.38 & 75.22 \\
\hline
\end{tabular}

\subsection{Traditional Preparation Steps of Smen/Dhan}

Based on the survey results, we could define the different steps used for the preparation of traditional "Smen/Dhan" (Figure 2, 3). These steps are described below.

\subsubsection{Raw Material Used}

Raw milk of different animal species can be used in order to make butter, which is then further processed to Smen/Dhan. Based on the survey results, it was found that, cow, goat and sheep milk or mixture of two milk types (goat and sheep milk) could be used to produce butter, and the milk type differed significantly between eastern and southern regions. Indeed, cow's milk is the most widely used milk in the eastern regions with 73.97, $100,70 \%$ and $100 \%$ of interviewed households using cow's milk in Batna, Jijel, Khenchela and Setif localities, respectively. In contrast, in the Southern regions, goat's milk is mostly used for the preparation of Dhan, with 92.75\%, 98.68\% and 100\% of interviewed households preparing Smen/Dhan with goat milk in Biskra, Ouargla and El Oued localities, respectively. Concerning sheep milk, its utilization is scarce and most of the time, it is used in mixture with goat milk. It is not surprising that the milk type differs between Eastern and Southern regions as it reflects the most prevalent bred animals in these two regions.

\subsubsection{Milk Coagulation}

After milk collection, raw milk is spontaneously fermented at room temperature until coagulation with a duration time varying from 12 to $120 \mathrm{~h}$ depending on the season at which this fermentation is performed. Indeed, in the summer season, because of higher temperatures, the fermentation time varies between 12 to $24 \mathrm{~h}$ while in the winter, it can last up to $120 \mathrm{~h}$. In order to accelerate the fermentation process in the winter season, some people add ingredients to the milk, such as lemon juice, vinegar, Raib (fermented milk), yogurt, klila (cheese) and/or hot water, or leave the milk to coagulate in front of heat or the fireplace. The obtained coagulum is called Raib and it may be consumed as it is or processed further as described below.

\subsubsection{Butter Making}

For butter making, Raib is then churned. Churning can be performed with several tools either manually using the traditional Chekoua which is a goatskin bag, an electric churn equipped with wood, metal, paddles or a plastic bottle (Figure 4).

In the past, Chekoua was the mostly used churning tool, but due to its decreasing availability as well as the better ease and speed of use of other tools, it disappeared gradually. Benkerroum and Tammim (2004) stated that the decreasing use of traditional churning tools was due to the fact that electric churns are faster and do not require much labour. In addition, these tools are easier to clean while Chekoua cleaning is more fastidious and laborious, and it can be easily contaminated by undesirable microorganisms including spoilage and pathogenic ones. On the other hand, this tool can be a source of beneficial microorganisms which could play a significant role in Smen/Dhan organoleptic properties, but this aspect has not been studied in detail so far.

Nevertheless, in Algeria, people still use the traditional Chekoua, especially people living in rural areas. Indeed, $21 \%$ of the surveyed population still used Chekoua for churning, while $41 \%$ and $38 \%$ use electric churns and 
plastic bottles or cans, respectively. With regard to churning duration, it varied depending on the churning tool used as well as the ambient temperature, quantity of Raib to be processed and its fat content which is also dependent on the animal species from which milk is derived. According to the surveyed population, it can last between 1 to $2 \mathrm{~h}$ using a traditional Chekoua or a bottle and between $30 \mathrm{~min}$ to $1 \mathrm{~h}$ using an electric tool. At the end of churning, a quantity of cold or hot water can be added in the mixture according to the ambient temperature, in order to favor the agglomeration of butter grains. This trick is also used by the Moroccans (Tantaoui-Elaraki, \& El Marrakchi, 1987). At the end of this process, two phases appear, a solid one called zebda i.e., butter and a liquid one called Lben, i.e., buttermilk. After that, the butter is collected by hand or using a strainer or a perforated ladle.

Concerning butter yield, $30 \mathrm{~L}$ of milk yield between 0.8 and $1 \mathrm{~kg}$ of butter, which is slightly lower than that reported by Alganesh and Yetenayet (2018) with 20 to $25 \mathrm{~L}$ of milk for $1 \mathrm{~kg}$ of butter. After churning, the butter is washed several times to remove Lben traces which constitute the aqueous phase.

\subsubsection{Smen/Dhan Preparation}

According to the surveyed households from East and South of Algeria, Smen/Dhan preparation is transmitted by identical method from generations. Its production is related to two main factors. First, Smen/Dhan is produced because it is an important ingredient in traditional foods, but also for its possible use in traditional medicine. The second reason is that Smen/Dhan production allows keeping the butter for longer time period. Indeed, butter transformation into Smen/Dhan leads to a more stable product from an organoleptic and microbiological point of view and thus prevent food losses. Benkeroum and Tamim (2004) also reported that the raw butter surplus exceeding the domestic demand, was transformed into Moroccan Smen for longer preservation.

It is also worth mentioning that among households preparing Smen/Dhan at home, $61.3 \%$ prepared the butter themselves at home starting from raw milk as described above, while the others did not and purchased butter directly from milkmen. These milkmen are traders who collect milk from farms, and sell milk and traditional dairy products to people in the area. These traders own large churns which are used for the preparation of Lben and butter. This was also true for households living in urban areas of the Eastern regions (Batna, Jijel, Setif and Khenchela), which did not transform themselves the raw milk into butter, but bought directly the latter from milkmen, in contrast to households from rural areas and those from the Southern regions. These traders also manufacture and sell Smen/Dhan but, in general, Smen/Dhan preparation is performed by their mother or wife following the traditional process.

After churning, the obtained butter can be processed immediately into Smen/Dhan, or the latter is only produced after the accumulation of a large butter quantity in the household. Indeed, we noted that $31.6 \%$ of households used to prepare Smen/Dhan, immediately processed the butter, while the remaining households only prepared Smen/Dhan after accumulation of large butter quantities. In the latter case, butter is kept in the refrigerator or at room temperature with a small amount of salt which allows storing butter for a longer time period as salt addition reduces food water activity and thus prevents the growth of non-halotolerant undesirable microorganisms. Interestingly, we observed that Smen/Dhan preparation method is different according to the surveyed region. This difference was observed between the regions of Batna, Khenchela, Setif on one hand and the regions of Biskra, El oued, Jijel, Ouargla. Indeed, following butter washing, households from regions of Batna, Khenchela, Setif proceed directly with butter salting (Figure 2, see section 3.3.2.1) while in others regions of Biskra, El Oued, Jijel, Ouargla, a different process is used which first involves a heat treatment of the butter (Figure 2, see section 3.3.2.2) followed by the addition of one or more ingredients. Both methods, together with the butter acidic $\mathrm{pH}$, relatively high salt $(\mathrm{NaCl})$ content, and its low moisture and water activity, contribute to the microbiological stability of the obtained products, which in turn increases butter shelf life (Sserunjogi, Abrahamsen, \& Narvhus,1998; Afsaneh, Hosseinpour, \& Mina, 2016; Alganesh, \& Yetenayet, 2017).

\subsubsection{Butter Salting}

As mentioned above, in certain localities, i.e., Batna, Khenchela, and Setif, people proceed directly to butter salting with a process similar to that of Moroccan Smen (Tantaoui-Elaraki \& El Marrakchi, 1987; Benkerroum \& Tamime, 2004). In the present study, 94\% of households preparing Smen/Dhan with this method add directly salt to the butter and this quantity varies from one household to another. The answers of the surveyed population were very diversified, and the interviewed people did not know exactly the salt concentration used, only the fact that the butter must be well salted. According to $60 \%$ of surveyed population and based on our estimation, the salt concentration varies between 50 and $80 \mathrm{~g} / \mathrm{kg}$ of butter. It is worth mentioning that certain households $(2.20 \%)$ add a quantity of matured Smen/Dhan (period of maturation between 2 years to 10 years) with recently prepared Smen/Dhan in order to minimize the maturation time and gives a result in a short time. Benkourroum and Tamim 
(2004) also reported that the ripening period of Moroccan Smen could be shortened to 30 days after mixing a portion (ca.5-8\%) of matured Smen with freshly made product.

After salt addition, butter is well kneaded allowing a homogeneous distribution of salt in the butter. People stated that the salt addition was necessary for better preservation and for taste improvement.

After salting, the salted butter is left for a certain time to get the water out, which is then removed, allowing a shelf-life extension of Smen/Dhan during storage. Salted butter can then be directly packaged for further maturation.

\subsubsection{Heat Treatment}

The use of heat treatment was adopted in Biskra, Jijel, El Oued and Ouargla localities. For this, the butter is heated at slow fire until melting. The melting temperature could not be defined precisely by the respondents, but they indicated that butter had to be slowly melted to avoid fatty degradation and for a better separation of Lben residues and impurities. This method is similar to that of Samna making in Egypt and to a smaller extent to Ethiopian and Indian Ghee. Indeed, for Samna, butter is heated under continuous stirring at 50 to $60^{\circ} \mathrm{C}$ while for Ethiopian and Indian Ghee, temperature can reach to $110^{\circ} \mathrm{C}$ at $120^{\circ} \mathrm{C}$, allowing the removal of more moisture and development of specific flavour (Sserunjogi, Abrahamsen, \& Narvhus,1998; Chaudhary et al., 2019). According to (Illingworth, Patil, \& Tamime, 2009), Ghee can be defined as a clarified pure fat which is obtained exclusively from milk, cream or butter by application of heat treatment leading to an almost complete elimination of moisture and solid fats.

At boiling point, white froth, which corresponds to residual Lben as indicated by the interviewed persons, appears on the melted butter surface. This froth is then skimmed off with a soup spoon, followed by the addition of different ingredients, the basic one being coarse semolina called Dchicha. Indeed, $92.5 \%$ of the population who prepared Smen/Dhan using this method, declared that they added Dchicha to butter during boiling under continuous agitation. The quantity of added Dchicha was usually approximate but the majority of respondents added $\sim 160 \mathrm{~g}$ of Dchicha per $\mathrm{Kg}$ of butter, the purpose of this addition being residual Lben and water absorption during cooking to obtain Smen/Dhan of good quality. According to (Sserunjogi, Abrahamsen, \& Narvhus, 1998) who focused on Ghee, after separation, the fat phase is further boiled together with a piece of bread and the boiling step is stopped when the bread becomes crispy and light brown in colour.

Besides Dchicha, $88.75 \%$ of them also added a small quantity of salt, $\sim 8 \mathrm{~g} / \mathrm{Kg}$ of butter. Moreover, $41.66 \%$ of respondents were adding herbs to flavor the product. These herbs were added by people of Biska, El Oued and Ouargla while those of Jijel did not use them. The different herbs, i.e., rosemary (Salvia rosmarinus), thyme (Thymus spp.), juniper (Junipirus spp.) and fenugreek (Trigonella foenum-graecum) mixtures, are added in small quantities (a pinch) to butter during cooking. Finally, $7.90 \%$ of respondents were also adding a small onion piece to the mixture. Hazra and Parmar (2014) reported that the addition of herbs can prevent oxidative rancidity of Ghee.

The cooking duration differed from one respondent to another with duration between 30 min and $1.5 \mathrm{~h}$. This variation was justified by the time needed for cooking and decanting the Dchicha semolina grains. At the end of cooking, the cooked butter is clarified with the semolina at the bottom of the pan. After this heat treatment phase, the product is filtered through using a sieve or a piece of a stamen to eliminate any trace of impurities and additives followed by packaging as described below.

The cooked semolina removed of melted butter is consumed by $35 \%$ of the respondents using this method. Nowadays, cooked semolina is considered as a traditional dish and is consumed for pleasure while in the past, it was also consumed to avoid food losses in a context of food shortage.

\subsubsection{Packaging, Maturation and Storage}

The packaging of salted or cooked butter is then carried out in containers made of glass ( $53.45 \%$ of the surveyed population preparing Smen/Dhan), plastic (34.04\%), or a traditional ceramic container called Ezzir (12.5\%). The latter type of container was mainly preferred by people from rural areas. The butter must be well compacted to remove air, so the pot must be fully filled to minimize free space. Some people declared that they covered the top a paste of semolina to completely prevent air entry. The ripening process was conducted in a dry place, in the dark and, at room temperature. In some cases, the product was left in the refrigerator, especially in the Southern regions of Algeria, because these regions are hot areas, especially in the summer. We noted that 53.45\%, $41.48 \%$ and 3.45\% of the population producing Smen/Dhan let it to mature at room temperature, in the refrigerator, or both depending on the season while $1.59 \%$ bury the Smen/Dhan underground. As previously reported by Benkerroum and Tamime (2004) for Smen made in several Morocco regions, the pot is buried underground to ensure darkness, 
anaerobiosis and to minimize temperature variations.

The maturation duration was different from one person to another, varying from one month to several years, according to the consumer preferences. As indicated by the respondents, Smen/Dhan has a strong characteristic taste which strength depends on the maturation time.

After Smen/Dhan maturation, most people utilize it as it is ( $90.42 \%$ of the population consuming Smen/Dhan) while $9.57 \%$ heated Smen/Dhan at a slow fire until melting, before filtration and storage at room temperature, to stop the Smen/Dhan maturation process.

As for all other dairy products, Smen/Dhan may undergo physico-chemical or microbiological alterations. These phenomena can take place during storage and affect its organoleptic properties (texture, taste). According to the surveyed population, most people (70\%) stated that they never experienced Smen/Dhan spoilage during storage. The others stated that they had observed mould spoilage on the Smen/Dhan surface which, according to the answers of some elderly people, was due to a default encountered during Smen/Dhan preparation and the remaining presence of Lben in the butter before packaging. Other spoilage encountered by consumers included rancidity defects, colour defect due to mould growth and unpleasant flavour development.

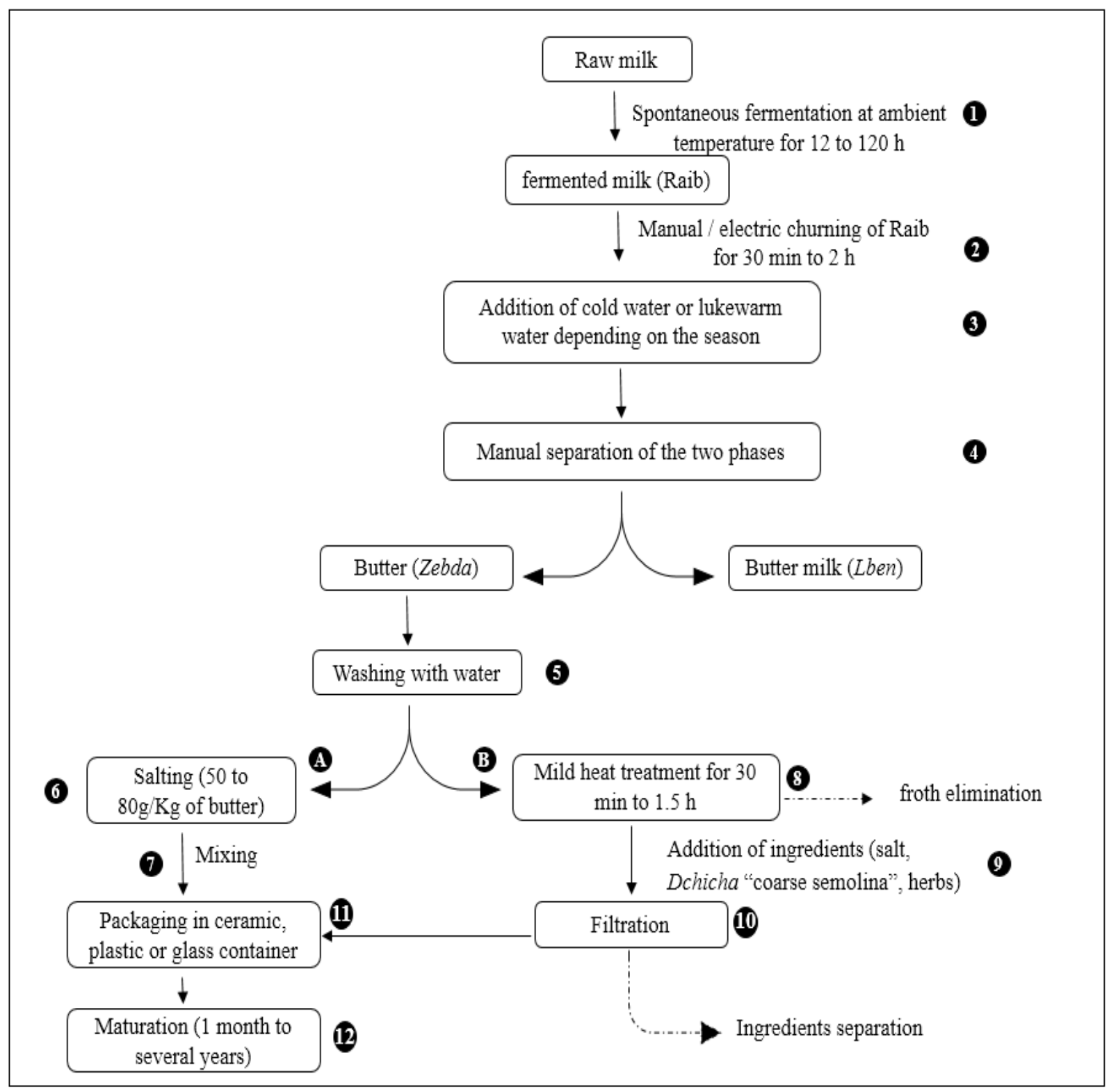

Figure 2. Diagram showing the different steps of traditional Smen/Dhan manufacturing 


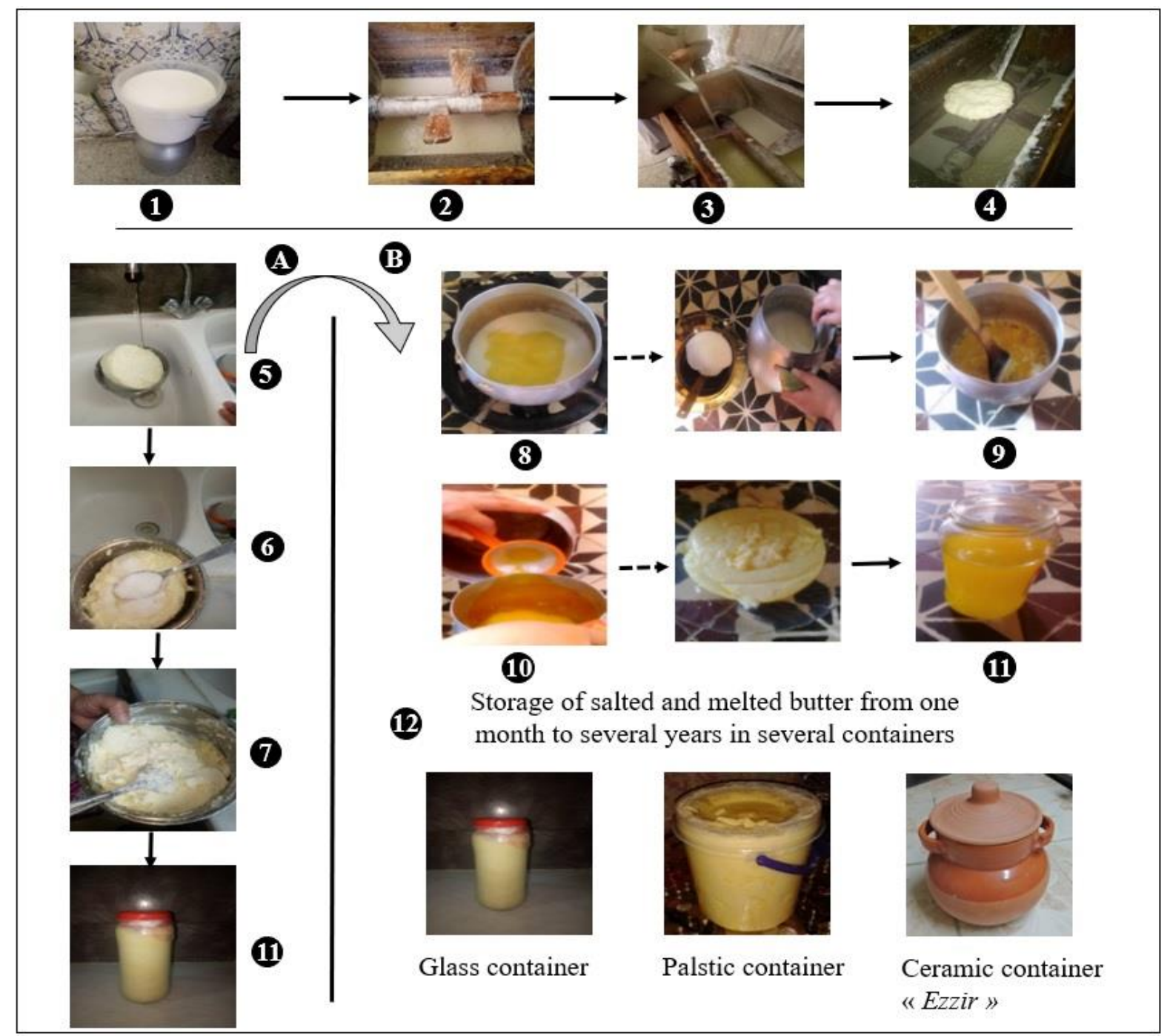

Figure 3. Photographs showing the different steps of traditional Smen/Dhan manufacturing

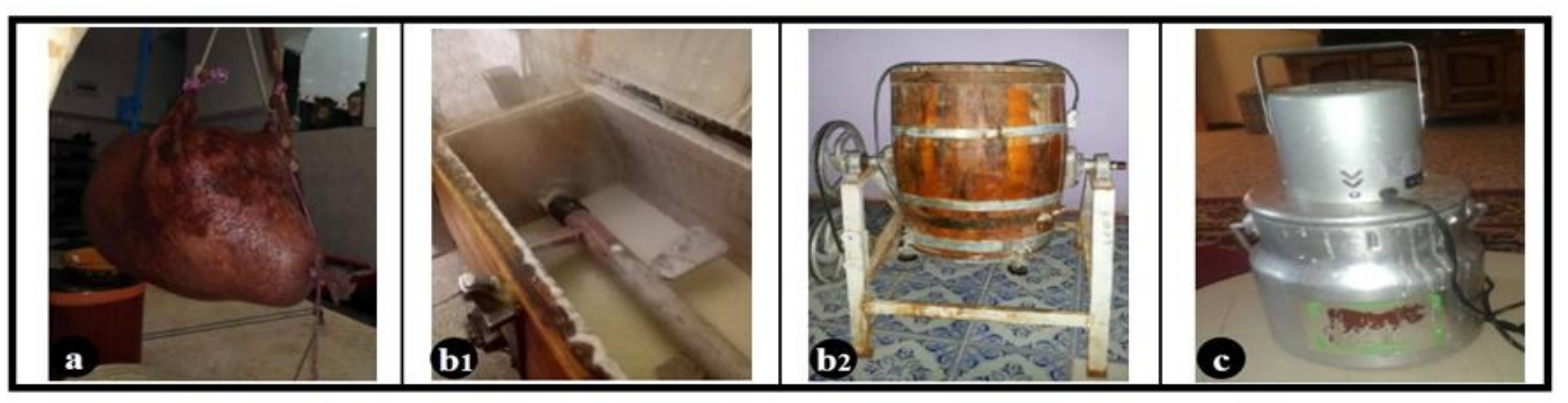

Figure 4. Different tools used for Rayeb churning (a: traditional Chekoua made from goat skin, $\mathbf{b}_{\mathbf{1}}-\mathbf{b}_{\mathbf{2}}$ : traditional churn in wood, c: electric churn)

\subsection{Smen/Dhan Consumption}

Regarding the use of Smen/Dhan in the local culture, and based on the answers of the surveyed population, the majority of the respondents used it for meal preparation and also consumed it alone. The consumption has different objectives, i.e., improving the taste and aroma of some traditional dishes or therapeutic purposes. Regarding culinary usage, people use Smen/Dhan with maturation age between 1 month to 2 years. Its characteristic taste depends on maturation time and this taste is stronger with a long maturation period. It is usually used at the end of cooking as a flavoring agent in some traditional dishes such as couscous, 
chekhchoukha and trida, for cooking meat, and for preparation of traditional cakes such as makrout, baklawa, mberdja, and rfis. This is in agreement with previous work that stated that ripened Smen, because it has a strong rancid and salty characteristic taste, is mostly used as a condiment to enhance the flavor of some traditional Moroccan dishes (Benkerroum, \& Tamime, 2004).

According to the results of this study, traditional Smen/Dhan ripened for more than two years is used for therapeutic purposes. This practice is much more observed in southern regions of Algeria, where it is occasionally drunk with coffee to treat cough. This practice was also reported for Ghee by Alganesh and Yetenayet (2017) who indicated that traditionally made Ghee stored for more than a year was recommended to treat chronic coughs. Smen/Dhan is also used to treat injuries, burns, migraine, headache, injury, hemorrhoids, flu and eczema with a superficial application. We also noted that some farmers use Smen/Dhan to treat trauma and injuries of their cows and other animals. The same applications in traditional medicine are also seen with Indian Ghee (Gandhi, \& Lal, 2015). The therapeutic effects of Smen/Dhan have not been studied so far but concerning Ghee, Ahmad and Saleem (2020) showed that it has a high concentration of conjugated linoleic acid which possess antioxidant, anticarcinogenic, antidiabetic and antiatherogenic properties (Chinnadurai, Kanwl, Tyagi, Stanton \& Ross, 2013).

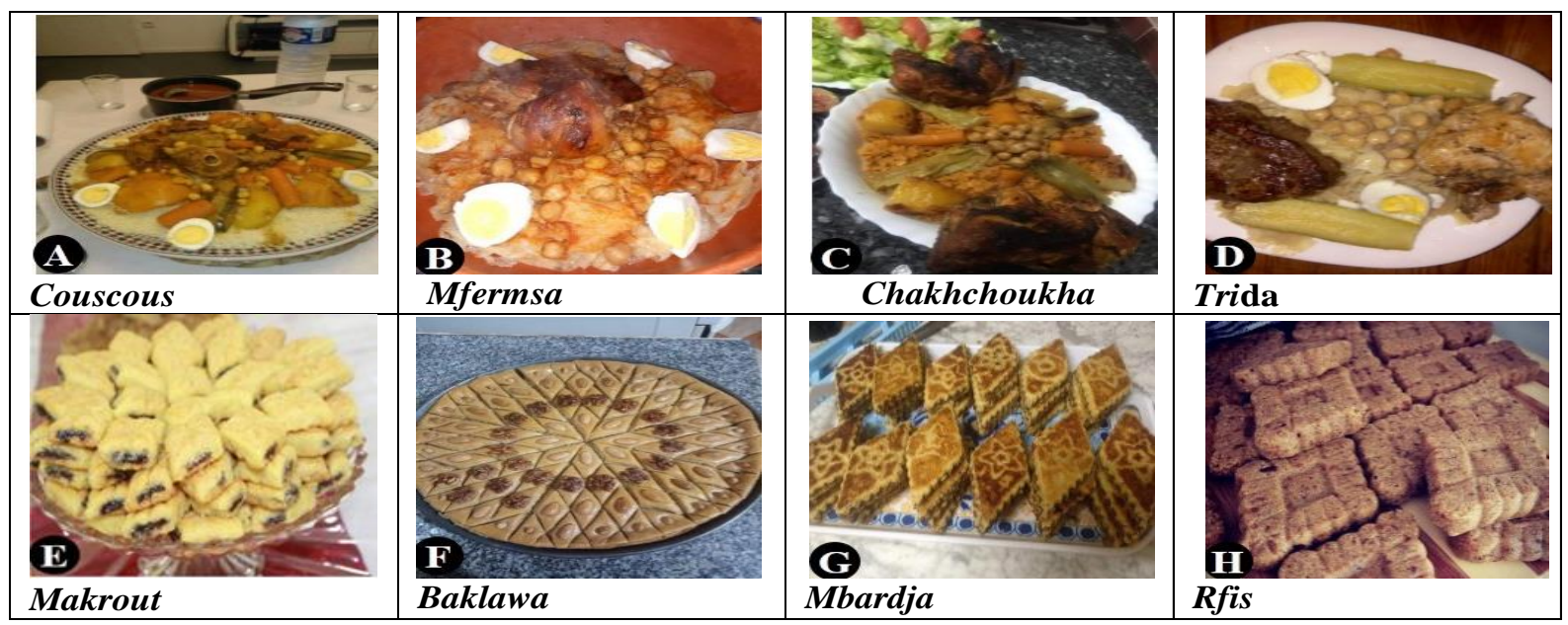

Figure 5. Photographs of some traditional foods (A, B, C, D) and pastries (E, F, G, H) prepared with Smen/Dhan matured for 1 to 24 months

\section{Conclusion}

Through this study, it was found that Smen/Dhan is an important product in the Eastern and Southern Algerian culture. It represents an ethnic food with a specific know-how and is part of Algerian eating habits. Smen/Dhan is prepared by housewives and takes an important place at the family level. This product is used for self-consumption, and it can be commercialized to provide an income for the family. Unfortunately, its marketing is generally in informal circuits because Smen/Dhan has not yet received any quality label despite its importance in traditional cooking and medicine. Therefore, it would be of great interest to create cooperatives that could market this product in a formal way while guaranteeing a better quality with a specific quality label. It could help local producers improving overall product quality and safety as well as to promote the gastronomic heritage of Algeria. Because the Algerian Smen/Dhan is a fermented food, it would be of great interest to study its microbial diversity and identify the key microorganisms involved in its sensory characteristics to better control fermentation processes and, thus, its quality attributes.

\section{Funding}

This work, which was conducted in the framework of the ProMedFoods project 'Promotion of local Mediterranean fermented foods through a better knowledge and management of microbial resources', was funded through the ARIMNet2 2016 Call by the following funding agencies: ANR (France), MERS (Algeria), ELGO-DEMETER (Greece), MIPAF (Italy), INIA (Spain) and MHESR (Tunisia). ARIMNet2 (ERA-NET) has received funding from the European Union's Seventh Framework Programme for research, technological development and demonstration under grant agreement no. 618127. 


\section{Acknowledgements}

The authors are grateful to the interviewed people, especially housewives who took part and gave up their time to this survey.

\section{Article publication agreement}

All authors have revised the final version and confirmed the publication in this journal.

\section{Conflict of interest}

The authors declare no conflict of interest.

\section{References}

Abd-El Salam, M., \& Benkerroum, N. (2006). North African Brined Cheeses. In Brined Cheeses. https://doi.org/10.1002/9780470995860.ch5

Afsaneh, M., Hosseinpour, H., \& Mina, A. (2016). Investigation of quality, advantages and disadvantages, processing and characteristics of ghee, Indian Journal of Fundamental Applied Life Sciences, 6, 1-7. Retrieved from http://www.cibtech.org/sp.ed/jls/2016/02/01-JLS-S2-JUNE-001-MINA-INVESTIGATION.pdf

Ahmad, N., \& Saleem, M. (2020). Characterisation of cow and buffalo ghee using fluorescence spectroscopy. International Journal of Dairy Technology, 73, 191-201. https://doi.org/10.1111/1471-0307.12632

Alganesh, T. G., \& Yetenayet, B. T. (2017). Traditional butter and ghee production, processing and handling in Ethiopia. African Journal of Food Science, 11(4), 95-105. https://doi.org/10.5897/AJFS2016.1544

Bekhouche, F., Merabti, R., \& Bailly, J. (2013). Lemzeiet traditional couscous manufacture from fermented wheat (Algeria): investigation of the process and estimation of the technological and nutritional quality. African Journal of Food Science and Technology, 4(8), 167-75. http:/dx.doi.org/10.14303/ajfst.2013.032

Benkerroum, N., \& Tamime, A. Y. (2004). Technology transfer of some Moroccan traditional dairy products (lben, jben and smen) to small industrial scale. Food Microbiology, 21, 399-413. https://doi.org/10.1016/j.fm.2003.08.006

Bensalah, F., Labtar, A., Delorme, C., \& Renault, P. (2011). Occurrence, isolation and DNA identification of streptococcus thermophilus involved in Algerian traditional butter "Smen". African Journal of Biotechnology, 10(75), 17251-17257. https://doi.org/10.5897/AJB11.2462

Chaudhary, B. N., Vaghela, K. D., Mehta, B. M., Jain, A. K., Darji, V. B., \& Aparnathi, K. D. (2019). Development of a Rapid Qualitative Test Using Ferroin Dye for Detection of Rancid Ghee Mixed with Fresh Ghee. Journal of Food Chemistry Nanotechnology, 5(3), 49-55. https://doi.org/10.17756/jfen.2019-071

Chinnadurai, K., Kanwal, H. K., Tyagi, A. K., Stanton, C., \& Ross, P. (2013). High conjugated linoleic acid enriched ghee (clarified butter) increases the antioxidant and antiatherogenic potency in female Wistar rats. Lipids in Health and Disease, 12, 121-129. https://doi.org/10.1186/1476-511X-12-121

Dhurvey, Y. R., Kawtikwar, P. S., \& Sakarkar, D. M. (2012). Evaluation of Physicochemical Properties of Cow Ghee before and after Hydrogenation. International Journal ChemTech Research, 4(1), 185-189. Retrieved from http://www.sphinxsai.com/2012/chem/CHEM/CT=31(185-189)JM12.pdf

El Sheikha, A. F., \& Hu, D. M. (2020). Molecular techniques reveal more secrets of fermented foods. Critical Reviews in Food Science and Nutrition, 60, 11-32. https://doi.org/10.1080/10408398.2018.1506906

Faid, M., Larpent, J. P., Adrian, Y., Chabard, J. L., Tantaoui-Elaraki, A., \& El Marrakchi, A. (1993). Industrial scale production of Moroccan samn. Journal of the society of Dairy Technology, 46, 9-11. https://doi.org/10.1111/j.1471-0307.1993.tb00851.x

Gagaoua, M., \& Boudechicha, H. R. (2018). Ethnic meat products of the North African and Mediterranean countries. Journal of Ethnic Foods, 5, 83-98. https://doi.org/10.1016/j.jef.2018.02.004

Gandhi, K., \& Lal, D. (2018). Potential of Herbal Nutraceuticals in Ghee: A Review. Research \& Reviews: Journal of Dairy Science and Technology, 4, 1-5. https://doi.org/10.37591/rrjodst.v4i2.412

Guessas, B., Adjoudj, F., Hadadji, M., \& Kihal, M. (2012). Isolation and identification of lactic acid bacteria from Dhan, a traditional butter and their major technological traits. World Applied Sciences Journal, 17(4), 480-488. Retrieved from http://www.idosi.org/wasj/wasj17(4)12/11.pdf 
Hazra, T., \& Parmar, P. (2014). Natural Antioxidant Use in Ghee-A Mini Review. Journal of Food Research and Technology, 2(3), 101-105. Retrieved from http://jakraya.com/journal/pdf/5-jfrtArticle_2.pdf

Hutkins, R. W. (2006). Microbiology and Technology of Fermented Foods. https://doi.org/10.1002/9780470277515

Idoui, T., Benhamada, N., \& Leghouchi, E. (2010). Microbial quality, physicochemical characteristics and fatty acid composition of a traditional butter produced from cows' milk in East Algeria. GRASAS Y ACEITES, 61(3), 232-236. https://doi.org/10.3989/gya.110209

Illingworth, D., Patil, G. R., \& Tamime, A. Y. (2009). Anhydrous Milk Fat Manufacture and Fractionation. In Dairy Fats and Related Products. https://doi.org/10.1002/9781444316223

Iradukunda, C., Aida, W. M. W., Ouafi, A. T., Barkouch, Y., \& Boussaid, A. (2018). Aroma profile of a traditionally fermented butter (smen). Journal of Dairy Research, 85, 114-120. https://doi.org/10.1017/S0022029917000796

Johansen, P. G., Owusu-Kwarteng, J., Parkouda, C., Padonou, S. W., \& Jespersen, L. (2019). Occurrence and Importance of Yeasts in Indigenous Fermented Food and Beverages Produced in Sub-Saharan Africa. Frontiers in Microbiology, 10, 1789. https://doi.org/10.3389/fmicb.2019.01789

Kacem, M., \& Karam, N. E. (2006). Physicochemical and microbiological study of "shmen", a traditional butter made from camel milk in the Sahara (Algeria): isolation and identification of lactic acid bacteria and yeasts. GRASAS Y ACEITES, 57(2), 198-204. https://doi.org/10.3989/gya.2006.v57.i2.37

Mortensen, B. K. (2011). Anhydrous Milk Fat/Butter Oil and Ghee. In Encyclopedia of dairy sciences (2nd Ed.), London, UK: Elsevier Ltd.

Pieniak, Z., Verbeke, W., Vanhonacker, F., Guerrero, L., \& Hersleth, M. (2009). Association between traditional food consumption and motives for food choice in six European countries. Appetite, 53, 101-108. https://doi.org/10.1016/j.appet.2009.05.019

Puniya, A. K. (2015). Fermented Milk and Dairy Products. New York: CRC Press. https://doi.org/10.1201/b18987

Rajorhia, G. S. (1993). GHEE. In Encyclopedia of Food Sciences and Nutrition. London: Academic Press Ltd.

Sakili, D., \& Isoual, D. (2003). Les bactéries lactiques dans l'élaboration du Smen marocain, Académie d'Agriculture de France. Retrieved from https://www.academieagriculture.fr/sites/default/files/publications/notes/2016/les-bacteries-lactiques-dans-1 elaboration-du-smen-marocain-par-dahmane-sakili-et-driss-issoual/2003notesbacterieslactiques.pdf

Sserunjogi, M. L., Abrahamsen, R. K., \& Narvhus, J. A. (1998). Current Knowledge of Ghee and Related Products. International Dairy Journal, 8, 677-688. https://doi.org/10.1016/S0958-6946(98)00106-X

Tantaoui-Elaraki, A., \& El Marrakchi, A. (1987). Study of Moroccan dairy products: lben and smen. MIRCEN Journal, 3, 211-220. https://doi.org/10.1007/BF00933574

Zamfir, M., Vancanneyt, M., Makras, L., Vaningelgem, F., Lefebvre, K., Pot, B., Swings, J., \& De Vuyst, L. (2006). Biodiversity of lactic acid bacteria in Romanian dairy products. Systematic and Applied Microbiology, 29, 487-495. https://doi.org/10.1016/j.syapm.2005.10.002

\section{Copyrights}

Copyright for this article is retained by the author(s), with first publication rights granted to the journal.

This is an open-access article distributed under the terms and conditions of the Creative Commons Attribution license (http://creativecommons.org/licenses/by/4.0/). 